\title{
Research on the Innovative Development of Inclusive Finance for the Rural Area in Hubei Province from the Perspective of Financial Poverty Alleviation
}

\author{
Xiaocui Deng \\ College of Finance and Business English \\ Wuhan Technology and Business University \\ Wuhan, China \\ e-mail:dengxiaocui0426@163.com
}

\begin{abstract}
Financial poverty alleviation is an important means of developing the rural economy. Inclusive finance can effectively improve the imbalanced allocation of financial resources and help to lift those farmers out of poverty. Based on the analysis of the poverty alleviation practice of inclusive finance in Hubei Province, this paper has proposed the solutions to some problems existing in the development course of inclusive finance and also facilitated the targeted measures in poverty alleviation in Hubei through inclusive finance.
\end{abstract}

Keywords-Inclusive finance; Financial poverty alleviation; Rural economy; Financial innovation

\section{INTRODUCTION}

Since the Reform and Opening-up, China has taken extensive measures to alleviate the poverty. Although China has made some remarkable achievements, it is still faced with a great challenge for poverty alleviation. According to the statistical communique by National Bureau of Statistics in 2017, there are still about 30.46 million people living below existing poverty line by the end of 2017. Because most of those poor people are living in the rural areas with scarce natural resources and remote geographical location, it has further worsened the poverty and also added to the difficulty in liberating them from poverty.

Considering that fund is a main bottleneck on the development of poverty-stricken areas, how to channel funds into poverty-stricken areas is an important task facing poverty alleviation. Because of the strict threshold for credit loan in the traditional financing, the poor and disadvantaged group is unlikely to have access to credit loan. As a result, it has worsened their poverty. While the development concept of inclusive finance is to bring financing solutions to those poor people living in the poverty-stricken areas, and also help them to get access to financial assistance and services. Therefore, developing inclusive finance is a crucial way of boosting rural economic development, and also an important measure to facilitate poverty alleviation.

\section{THE CONNECTION BETWEEN INCLUSIVE FINANCE AND FINANCIAL POVERTY} \section{ALLEVIATION}

\section{A. The Same Goal of Inclusive Finance and Financial Poverty Alleviation}

The goal of inclusive finance is to provide appropriate and effective financial services for all social classes and groups with financial needs at an affordable cost. It emphasizes on being inclusive. While the goal of financial poverty alleviation is to popularize various modern financial services in the poor countryside through the improvement of financial poverty alleviation system, and thus improve the rural economy fundamentally. Therefore, it can be seen that their goals are highly consistent with each other.

\section{B. The Same Mode of Inclusive Finance and Financial Poverty Alleviation}

Inclusive finance adopts a profitable mode of investment so as to provide financial services for all social groups at an affordable cost. By means of marketization, inclusive finance enables financial institutions to expand their financial services and pursue profits at the same time. Financial poverty alleviation can design accurate loan plans aimed at those poor people who have demands of financial services and the ability to return the interests and principal, who have the ability to open up business and create employment, helping to liberate the poor from poverty. Different from the traditional financial ways for poverty alleviation featured by fund input, they have the feature of opportunity creation, which means that they can provide those poor people with the opportunity to obtain financial resources and develop their ability to lift themselves out of poverty.

\section{THE POVERTY ALLEVIATION PRACTICE OF INCLUSIVE FINANCE IN HUBEI PROVINCE}

In recent years, many financial institutions in Hubei Province have carried out effective financial innovations with the purpose of supporting the rural economic development and serving those farmers. They have already made some achievements relevant to poverty alleviation in the form of inclusive finance.

\section{A. Yunongtong - Financial Services in aid of Rural Areas}

In order to facilitate the financial development of inclusive finance and accelerate the establishment of a multi-level rural financial service system, Hubei Branch of China Construction Bank officially initiated the financial services in aid of rural areas, which is called Yunongtong, in October of 2014. Through the service channels of supply and marketing cooperatives all over the province, a 
rural banking mode featured by mobile phone, supply\& marketing service outlet and Yunong card, has been built in the administrative villages so that rural peasant households can have easier access to financial services. The binding of Yunong card and phone number can realize five major functions, namely withdrawal, remittance, transfer, payment and balance inquiry and offer five preferential services, including the free petty account management, free annual management, free short-message service in the first year, free remittance procedure nationwide and free remittance to the hometown from the remote bank.

By the end of 2016, there had been about 67 thousands of bank service outlets offering the inclusive finance of Yunongtong to over 70 thousands of administrative villages. Those farmers can apply for basic bank services without leaving their villages, thus solving the last-mile problem of rural financial services.

\section{B. Financial Service Grid}

At the beginning of 2015 , the strategy of financial service grid was implemented in Hubei Province, which provided a new idea for the practice of inclusive finance. To be more specific, the town, sub-district, community and village were classified into a number of grids. Each grid was transformed into a financial service work station. The responsibility for each bank was also clearly defined and implemented. The grid personnel were responsible for collecting the information about the financial needs of those enterprises and residents, and also sending relevant information to the relevant bank.

As of December of 2017, 32.1 thousands of work stations for inclusive finance grid had been established in Hubei province. The loan worth 127.8 billion RMB in total had been issued, covering 3,992 town grids and 21.6 thousands of rural grids in the whole province. Besides serving 'Three Rural Issues', countryside and farmers, they had also brought benefits to 1.04 million small-andmicro businesses and low-income urban residents. Financial service grid had provided a platform for serving the 'Three Rural Issue' agriculture, countryside, farmers and small-and-micro businesses so that those people at the grassroots level had more opportunities for finding employment and becoming rich. It could also effectively reduce the factors leading to social instability.

\section{Financial Services Entering the Countryside and Rural Households}

In 2014, the Rural Credit Cooperatives of Hubei Province actively pushed forward the financial service activities for entering the countryside and rural households. Tens of thousands of banking personnel entered more than 10 thousand villages and rural households so as to popularize the financial knowledge as well as bring credit, bank card, phone number for account transfer, phone bank and inclusive finance services to the rural area. The Rural Credit Cooperatives of Hubei Province made great efforts to bring bank service outlets to those villages, make phone banks accessible to rural households as well as bring phone bank to those villages. In the first year, the activity extended to 2,128 service outlets and also included 4,026 automatic teller machines covering those villages and towns. 83 thousand phones for account transfer called Kalefu were installed. The number of phone bank users in the rural area exceeded 1.3 million. Thanks to those measures, numerous farmers could obtain financial services, such as petty withdrawal and transfer, without leaving their villages.

\section{THE PROBLEMS EXISTING IN THE POVERTY ALLEVIATION PRACTICE THROUGH INCLUSIVE FINANCE IN HUBEI PROVINCE}

Although Hubei has made some achievements for the poverty alleviation through inclusive finance, this large agricultural province with a large rural population and imbalanced urban-rural economic development is still faced with some tricky problems related to poverty alleviation through inclusive finance.

A. The Incomplete Inclusive Finance System and the Shortage of Financial Institutions Offering Poverty Alleviation Services for the Rural Area

In recent years, great efforts have been made to boost the financial development in the rural areas of Hubei Province. The basic coverage of financial services, such as account transfer through mobile phone, ATM and POS device, has been realized. However, the corresponding financing services have not been available in these rural areas. Large financial institutions giving poverty alleviation services to the rural areas in Hubei Province include China Development Bank, Agricultural Development Bank, Rural Credit Cooperatives, Agricultural Bank of China and Postal Savings Bank of China. Among them, those non-commercial banks, such as China Development Bank and Agricultural Development Bank, have few service outlets in these rural areas. Agricultural Bank of China and Postal Savings Bank of China also have few service outlets at the town level. Rural Commercial Bank has the largest number of service outlets in the rural area. At present, the Rural Credit Cooperatives of Hubei Province has completed the system reform of becoming rural commercial banks. More than 70 percent of over 2,000 service outlets of Rural Commercial Bank in the province are located at the county level or below. The loans for the farmers accounted for more than 70 percent of the rural loans of the commercial banks in the whole province, thus playing a major role in the rural financial poverty alleviation. However, the system reform of the bank is still faced with some problems, such as the short period of the reform, the backward commercial mode and service means as well as incomplete information about peasant households. As a result, it has hindered the provision of financing services for the rural area, which means that the effect of poverty alleviation still remains to be improved

\section{B. The Rural Financial Services Lacking an Effective Incentive Mechanism}

Although the central and local governments have released a large number of preferential policies related to the loan aimed at the rural area, there still lacks an effective incentive mechanism. For example, the Ministry 
of Finance and State Administration of Taxation released the Circular about Resuming and Improving the Tax Policies Supporting the Rural Financial Development (Financial Tax [2014] Number 102) regarding the exemption of business tax for the petty loan issued by financial institutions to peasant households. The petty loan in the circular means the single loan whose balance is below 100 thousand RMB. Considering that most poor farmers apply for the loan lower than 100 thousand RMB, it can only offer limited preferential treatment to the financial institution. Moreover, as a key role for developing the inclusive finance in Hubei, the Rural Commercial Bank has just finished the system reform. Due to the weak ability to deal with the fund and risk as well as the lack of the strategic support for risk compensation system and reward system, the Rural Commercial Bank has been less capable of serving the disadvantaged group such as peasant household.

\section{The Poor Rural Credit Environment}

As a large agricultural province, Hubei has a rural population of about 25 million. The wide rural area has been impacted by the poor economic environment and limited education resource. Most farmers are not well educated and also have a weak awareness of credit. Because of the shortage of service outlets of financial institutions and the limited opportunity to participate in financial activities for poor people, most farmers have no access to financial products and services and thus maintain a blank credit record. The lack of credit record has also discouraged those financial institutions from expanding their credit loan business. In addition, some poor people have viewed the credit loan fund as a form of relief and lacked the motivation to engage in production and lift themselves out of poverty. As a result, they can not repay the credit loan. Due to the limited judicial authorities and the difficulty in enforcing the law in the poverty-stricken area, many farmers can easily avoid being punished by the law after violating the relevant contract. With the increasing non-performing loans, those financial institutions are seriously discouraged from issuing more loans in aid of poverty alleviation.

\section{The Financial Services and Products Lacking Diversity and Accuracy in the Rural Area}

The financial services and credit loan products for the rural area in Hubei Province are lacking in diversity. For example, the Rural Commercial Bank in Hubei currently provides the loan services for peasant households, including mortgage loan, co-guarantee loan for professional rural organization members, petty credit loan, mortgage loan for water and intertidal operation rights and the mortgage loan for forest ownership. Because of the diverse low-value mortgages of peasant households, those financial institutions have much difficulty in issuing the loan. Moreover, in some areas, many young labors look for employment in other provinces, remaining many vulnerable groups such as low-insured households, widows, lift-home women and children. However, many financial products have strict regulations in the ages of lenders, which could cause different amount of loans and repayment. Therefore, it is different for these vulnerable groups to obtain loans.

Moreover, different poor households have different needs for the loan amount, loan period and mortgage item. Due to the constraint of the bank management system, the financial products designed and developed by financial institutions can not well satisfy farmers' financial needs. Those financial service outlets at the grassroots level are able to identify their financial needs accurately, but they can not participate in the design and development of financial products. As a result, the financial products for the rural area can not satisfy farmer's needs accurately.

\section{SOME POLICIES AND SUGGESTIONS FOR INNOVATING IN THE POVERTY ALLEVIATION MECHANISM THROUGH INCLUSIVE FINANCE IN THE RURAL AREA OF HUBEI PROVINCE}

\section{A. Complete the Rural Financial Service System}

In order to solve the problem of the incomplete rural financial service system, local governments must play an important role in guiding and encouraging financial resources to lean towards poverty-stricken areas. Besides accelerating the establishment of the multi-level modern agricultural financial system with a wide coverage, they should also encourage financial institutions to expand the business related to agriculture, countryside and farmers. They should also make great efforts to develop the mutual bank, cooperative bank and lease bank as well as expand the coverage of financial service outlets benefiting the rural areas. The policy functions of non-commercial banks should be enhanced and the mid-term and long-term credit loan for agriculture, countryside and farmers should be also increased. Further efforts should be made to boost the internet financial services in the form of internet bank, phone bank and mobile phone bank. Internet service platforms should be also established. The service efficiency and quality should be improved. The internet finance for the rural area should be also guided.

\section{B. Establish an Appropriate Incentive and Constraint Mechanism for the Rural Financial Poverty Alleviation}

The motivation of financial institutions to support the rural area is closely related to the governmental incentive and constraint. Firstly, the government should establish an evaluation mechanism for the financial poverty alleviation as well as give reward to those financial institutions serving the agriculture, countryside, farmers and countylevel economy. They should publicize those financial institutions that have achieved the goal of fully covering the rural area with financial services and also offered some material incentive. For those financial institutions that have failed to achieve the goal, they should receive some material punishment, such as the increase of tax rate. Secondly, the supervision over rural financial institutions should be tightened so as to avoid the excessive loan and relevant risk as a consequence of material incentive.

At the same time, agricultural insurance should be advocated in these poverty-stricken areas, which can help to establish risk prevention mechanism and risk compensation mechanism. Every level of provincial and 
municipal country administration should take advantage of common resources to establish thee compensation fund of poverty alleviation loan risks, taking the risks of the losses from the financial loans together. This is beneficial for the sustainable development of poverty alleviation through inclusive finance.

\section{Improve the Credit Environment}

Great efforts should be made to enhance the popularity of financial knowledge in the rural area of Hubei, strengthen farmers' financial knowledge and credit awareness as well as enhance the credit environment. In addition to further improving the coverage of credit investigation, the government should also improve the coordination and cooperation between different functional departments as well as promote the sharing of creditrelated information. Based on the credit rating system, financial institutions should also rate the credit of each peasant household and realize the automatic credit rating and extension. By means of credit rating, they will be able to keep track of the dynamic information about poor peasant households accurately and give the loan accordingly. The discredit punishment mechanism should be also further improved to prevent those poor peasant households from refusing to repay the loan and reduce the bad loan rate of relevant financial institutions.

\section{Innovate in the Rural Financial Product and Service Mode}

Based on the local environment, the financial institutions in Hubei must make greater efforts to innovate in financial products and services of inclusive finance aimed at poverty-stricken areas. Hence, a diverse product system will be formed to satisfy various financial needs. The cooperative channels between non-commercial banks, commercial financial institutions and rural mutual cooperatives should be expanded. The financial leasing services, such as agricultural machinery, should be encouraged. The pilot mortgage loan for the rural and contractual management right should be stabilized. The registration system for the forest mortgage should be completed. The new form of mortgage and guarantee with the subject of agricultural machinery can be promoted and the petty loan in aid of the independent business of peasant households can be provided. A portion of the governmental fund in aid of the rural area can be provided to support the development of the new-type rural financial institutions, mutual fund for poor villages and farmer professional cooperative in the form of loan by mandate and share holding by investment through the marketization operation platform.

\section{ACKNOWLEDGMENT}

Fund Project: Guiding Project of Scientific Research Program of Hubei Provincial Department of Education, 'Evaluation and Influencing Factors of Inclusive Financial Development in Rural Areas of Hubei Province' (Number: B2017319). Science and Research Program in Wuhan Technology and Business University, 'Research on the Development Path of Inclusive Finance in Rural Areas of
Hubei Province from the Perspective of Financial Poverty Alleviation' (Number: A2017001).

\section{REFERENCES}

[1] Chen Jianwei and Chen Yine. The Reflection on the Theories and Policies of Inclusive Finance Facilitating Targeted Measures in Poverty Alleviation. Contemporary Economic Research. 2017(5): $85-90$.

[2] Zeng Zhiming and He Hongjing. The Research of the Strategy for Inclusive Finance Supporting the Targeted Measures in Poverty Alleviation. Credit Investigation. 2017(2):10-14.

[3] Meng Xiaoli and Lu Lingyu. The Research of Rural Financial Poverty Alleviation under the Background of Inclusive Finance [J]. Regional Financial Research. 2015(7): 84 - 90

[4] You Shengguang. The Research of Inclusive Finance and Targeted Measures in Poverty Alleviation [J]. Contemporary Economics. 2016(5):62-65.

[5] Hua Hongyi. The Research of Policy Conduction Mechanism of Developing Financial Services for Poverty Alleviation - From the Perspective of the Efficiency of Developing Financial Services for Poverty Alleviation. Finance and Economics. 2015(6):45 - 48. 